\title{
'The Trial the World is Watching': The 1972 Prosecution of Derk Crichton and James Watts, Abortion, and the Regulation of the Medical Profession in Apartheid South Africa
}

\author{
SUSANNE M. KLAUSEN* \\ Department of History, Carleton University, 1125 Colonel By Drive, Ottawa, Ontario, \\ Canada, K15 5B6 \\ Honorary Research Fellow, Department of Historical Studies, University of Johannesburg, \\ Johannesburg, Gauteng, South Africa
}

\begin{abstract}
After its formation in 1910 as a self-governing dominion within the British empire, the Union of South Africa followed a combination of English and Roman-Dutch common laws on abortion that decreed the procedure permissible only when necessary to save a woman's life. The government continued doing so after South Africa withdrew from the Commonwealth and became a republic in 1961. In 1972 a sensational trial took place in the South African Supreme Court that for weeks placed clandestine abortion on the front pages of the country's newspapers. Two men, one an eminent doctor and the other a self-taught abortionist, were charged with conspiring to perform illegal abortions on twenty-six white teenagers and young unmarried women. The prosecution of Dr Derk Crichton and James Watts occurred while the National Party government was in the process of drafting abortion legislation and was perceived by legal experts as another test of the judiciary's stance on the common law on abortion. The trial was mainly intended to regulate the medical profession and ensure doctors ceased helping young white women evade their 'duty' to procreate within marriage. Ultimately, the event encapsulated a great deal about elites' attempt to buttress apartheid culture and is significant for, among other reasons, contributing to the production of South Africa's extremely restrictive Abortion and Sterilisation Act (1975).
\end{abstract}

Keywords: Abortion, Crime, Culture, Legislation, Reproduction, Sexuality, South Africa 
Prior to the passage of the Abortion and Sterilisation Act (1975) South Africa had no statutory law pertaining to abortion. After its formation in 1910 as a self-governing dominion within the British empire, South Africa followed a combination of English and Roman-Dutch common laws on abortion that decreed the procedure permissible only when necessary to save a woman's life. ${ }^{1}$ Nevertheless, South African women, in common with women around the world and across time, circumvented the law in order to terminate unwanted pregnancy. ${ }^{2}$ During apartheid (1948-90), the era of white supremacist National Party (NP) rule, clandestine abortion became what can only be described as an epidemic: by the 1960 s an estimated 200,000 women were procuring illegal abortions annually, the vast majority black. ${ }^{3}$ In 1970 approximately 4000 Indian, 15000 Coloured, 18000 white, and 123000 African women had clandestine abortions and, by the late 1970s, it was estimated that one out of every nine pregnant South Africans illegally terminated her pregnancy. ${ }^{4}$ Methods varied according to race and class: white women with means turned to private doctors and, after 1967, travelled to Britain for medical abortions. Black and poor white women hired untrained abortionists who injected liquids (commonly, soapy water or disinfectants, like Dettol) or inserted objects, or else they attempted to initiate miscarriages themselves in myriad dangerous ways. ${ }^{5}$ In addition, among the majority population of Africans, many women, especially in rural areas, continued utilising the services of traditional herbalists. ${ }^{6}$

The underground abortion industry became visible in the 1960s, by which time thousands of women were arriving annually at the casualty wards of hospitals in urban centres around the country as a result of incomplete or botched abortions (the latter referring to cases of infection or perforation). The issue of abortion migrated from the shadows of respectable society into the public spotlight when a range of professional and liberal feminist groups inspired and emboldened by the liberalisation of abortion laws in Europe and North America began calling for greater accessibility to medical abortion. Initially the NP Government ignored calls for abortion law reform. The apartheid sex code, imposed and policed by the authoritarian regime, was ultra-conservative: puritanical, patriarchal and heterosexist, built upon the ideal of the traditional family in which a

${ }^{1}$ In 1910 South Africa emerged as a white-minority-ruled British dominion comprised of the former British colonies of the Cape and Natal, and the former Boer republics of the Transvaal and Orange Free State. For an accessible overview of the formation of modern South Africa see William Beinart, Twentieth-Century South Africa (Oxford and New York: Oxford University Press, 2001).

2 John Riddle, Eve's Herbs: A History of Contraception and Abortion in the West (Cambridge, MA: Harvard University Press, 1997).

${ }^{3}$ During apartheid there were four official racial categories, Bantu (African), European (White), Asian and Coloured. Coloured refers the to the mixed-race descendants of the original Boers, indigenous Africans and slaves from other regions brought to the Cape, and whose mother tongue is Afrikaans. Note that, following the Black Consciousness Movement, I use the term 'black' to refer collectively to the racial categories the state called 'non-European'.

${ }^{4}$ Helen Bradford, 'Herbs, knives and plastic: 150 years of abortion in South Africa', in Teresa Meade and Mark Walker (eds), Science, Medicine and Cultural Imperialism (London: Macmillan, 1991), 136, 139. Pam Sharratt, a feminist lecturer in psychology at the University of Natal and member of the Abortion Reform Action Group, estimated that the number was as high as 220,000 annually in '220,000 Abortions a Year', Daily News, 6 March 1972. See also: 'Shock Abortion Death Toll in South Africa', Sunday Times, 11 March 1973; 'Abortion - Facing the Facts', Star, 31 January 1975.

${ }^{5}$ At least some Indian girls and women had access to medical abortionists in Durban, the site of the University of Natal's medical school for 'non-Europeans', the only institution for training African, Indian and Coloured doctors. For a history of the medical school see Vanessa Noble, A School of Struggle: A History of the Durban Medical School and the Education of Black Doctors in South Africa (Pietermaritzburg: UKZN Press, 2013).

${ }^{6}$ See Bradford, op. cit. (note 4), for discussion of methods utilised. 
woman was subservient to the paterfamilias and her role was to produce and raise children. Demands for greater access to medical abortion were anathema to the NP, which believed a woman's reproductive sexuality should be under male control. Ultimately it was criticism of the common law by the male-dominated medical and legal professions that led to official dissatisfaction with what the national newspaper The Argus summed up as a 'confused and unsatisfactory legal situation'. ${ }^{7}$ By the early 1970s the courts had shown ambivalence towards the common law in high-profile prosecutions of medical abortionists, thereby throwing the law's authority in serious doubt and forcing the government to act. The cabinet agreed that legislation was required and in February 1972 parliament was told that the Department of Health was already drafting legislation, and that it was hoped the bill would be ready for public comment before the end of the session. Yet months passed and no bill emerged. ${ }^{8}$

Then in November 1972 a sensational trial took place in Durban Supreme Court that for weeks splashed the topic of clandestine abortion across the front pages of the country's newspapers (South Africa did not have television until 1976). ${ }^{9}$ Two men were prosecuted for conspiring to perform illegal abortions on white teenagers and unmarried young women: Derk Crichton (b. 1920), a renowned doctor, and James Watts (b. 1931), a self-taught abortionist. The men were accused of 'acting in concert' to procure twentysix abortions and one attempt to procure abortion. ${ }^{10}$ At a moment when the country awaited the government's proposed new abortion law, the prosecution of an eminent doctor attracted widespread attention. In addition to being perceived by legal experts as another test of the judiciary's stance on the common law on abortion, ${ }^{11}$ the trial provided shocking proof to (white) South Africa that to an alarming degree, white girls and young women were flouting patriarchal values and having premarital sex. This confirmed what the regime already suspected: apartheid morality was weakening as a result of infiltration of 'liberal' Western values from the corrupt West.

Examining the trial is useful to historians of medicine and sexuality in South Africa for it encapsulated a great deal about the politics of reproduction during the 'golden age of apartheid'. ${ }^{12}$ The essay argues that the purpose of prosecuting Crichton and Watts was to shore up apartheid morality by disciplining, first, a high-profile representative of the liberal wing of the medical profession in order to stop doctors assisting girls to separate sex from marriage, and second, to stop white girls themselves from transgressing the apartheid sex code. The moral regulation of the ruling minority white population is an under-studied aspect of apartheid, as is the aspect of the state's efforts to police the medical profession. In what follows, I briefly discuss abortion and the law before apartheid; introduce Crichton

\footnotetext{
7 'SA's Abortion Deathrate "Appalling”, The Argus, 26 September 1973.

${ }^{8}$ Susanne M Klausen, “" "Reclaiming the White Daughter's Purity”: Afrikaner Nationalism, Racialised Sexuality and the 1975 Abortion and Sterilization Act in Apartheid South Africa', in special issue on 'Reproduction, Sex and Power", Journal of Women's History, 22, 3 (2010), 39-63.

9 'Trial the World is Watching', Sunday Tribune, 26 November 1972. In fact, it appears that only South Africans were watching; the assumption that international newspapers were covering the trial was just that, an assumption born out of a conviction of its importance.

10 'Warrant to Summon Accused and Serve Notice of Trial in the Supreme Court of South Africa', 3, Derk Crichton Papers, Killie Campbell Africana Library, University of KwaZulu-Natal (hereafter Crichton Papers).

11 'Abortion Case Judgment Surprise', Natal Mercury, 6 December 1972.

12 The term refers to the years 1964 to 1972 when the South African economy grew by an average annual rate of 6 to 8 per cent and political opposition had yet to recover from the repression of the early 1960s. Dan O'Meara, Forty Lost Years: The Apartheid State and the Politics of the National Party, 1948-1994 (Athens: Ohio University Press, 1996), 172-3.
} 
and Watts, and explain their abortion-related ideas, activities and relationship; and describe the police investigation and prosecution of the two men. Throughout, the essay probes events associated with the trial for meaning and significance in relation to the policing of sexuality and the provision of reproductive health care during apartheid.

\section{Abortion and the Law before Apartheid}

For the first half of the twentieth century the clandestine abortion industry seems to have been tacitly accepted by South African law enforcement officials. Generally abortionists, medical and untrained alike, were prosecuted only in the aftermath of a woman's death when the police could no longer look the other way. Similar situations had existed elsewhere; in the United States (USA), for example, during the first half of the twentieth century an 'unwritten agreement' existed that there was 'no prosecution unless there was a death'. ${ }^{13}$ The impression that 'criminal' abortion was tolerated by the police is reinforced by Watts who says he performed abortions on the girlfriends of police officers (see below), as well as by events surrounding an equally sensational abortion trial that occurred twenty years prior to the Crichton-Watts prosecution. In 1948 Dr Gerhardus Buchner, Dr Edward Blumberg and a nurse named Susanna Pieterse were arrested for providing abortions in an extremely busy and lucrative abortion clinic located at Castle Mansions in Eloff Street in downtown Johannesburg. ${ }^{14}$ Buchner, a South African doctor who received his medical degree at the Sorbonne, was in charge of the clinic that had been open since at least 1942. The clinic's services were in high demand; white women came from all four provinces as well as from outside South Africa. ${ }^{15}$ A nurse who once worked for Buchner testified that she looked after up to nine women at a time at the clinic. ${ }^{16}$

The clinic operated discreetly and the need for secrecy meant that abortions performed at night were lit only by flash lights because it was feared electric lights would attract unwanted attention. Yet the Johannesburg police knew about Buchner's clinic and for years tolerated its existence, probably because of bribes. ${ }^{17}$ In fact it was an official complaint made to police in Pretoria, located $60 \mathrm{~km}$ (37 miles) from Johannesburg, by a man determined to have the clinic exposed that spurred the investigation. ${ }^{18}$ During the trial the Attorney-General for the Transvaal, F.E. Lutge, accused the police of colluding in Buchner's 'gigantic practice' because for years he had operated 'on the main thoroughfare' of Johannesburg 'apparently quite openly'. Moreover, in 1943 Buchner was listed as an 'abortionist' in an official report by police, and, in 1946, an Afrikaans newspaper, the Weekblad, published a story about his practice in an article entitled 'Aborsie in Johannesburg' ('Abortion in Johannesburg'). Lutge said police officials had even 'wined and dined' at Buchner's premises in Castle Mansions. ${ }^{19}$ The lack of official action led the Attorney-General to surmise the police must have 'connived at the practice of abortion in

\footnotetext{
${ }^{13}$ Ricky Solinger, The Abortionist: A Woman Against the Law (New York: Macmillan, 1994), 14.

14 'Two Doctors in Court', Daily News, 12 November 1948.

15 'Doctors in Court: More Evidence is Heard', Daily News, 20 January 1949.

16 'Nurse, Gynaecologist Give Evidence at Preparatory Inquiry', Daily News, 9 February 1949.

17 Solinger discusses abortionists' 'dutiful' payment of bribes to police in The Abortionist, 15.

18 The man seems to have pursued Buchner out of retaliation: after he realized the real reason for his cousin's visit to the clinic - she had initially told him she needed treatment for varicose veins - he demanded return of the money paid for the abortion but Buchner refused. 'Buchner said to have banked 87,000 in two years', Natal Witness, 11 February 1949.

19 'Rand Abortion Trial: Gaol for All Accused', Natal Witness, 11 August 1949; 'Police Wined and Dined with Abortionists: Knew of Buchner Six Years Ago', Natal Mercury, 11 August 1949.
} 
Castle Mansions' ${ }^{20}$ and the case of this well-known clinic suggests that police for decades must have turned a blind eye to clandestine abortion elsewhere. After the convictions of Buchner, Blumberg and Pieterse the clandestine abortion industry once again receded to the shadows until the late 1960s when the changed cultural climate made abortion a highly visible and important political issue, to the degree that the government found it expedient to destroy the career of another medical abortionist, Dr Derk Crichton.

\section{The Defendants}

\section{Derk Crichton}

Derk Crichton qualified as a doctor in 1944 at the University of Cape Town (UCT), where his father E.C. Crichton held the Chair in the Department of Obstetrics and Gynaecology for many years. ${ }^{21} \mathrm{He}$ earned a first class in surgery at UCT, obtained a Doctor of Philosophy in radiological gynaecology and obstetrics in 1952 from Oxford, and became in 1954 one of the first clinical professors at the medical school at the University of Natal in Durban. ${ }^{22}$ At the age of 32 he took up the position of Chair of the University of Natal's Department of Gynaecology and Obstetrics. At the time of his arrest in 1972 Crichton was managing the gynaecology and obstetrics ward located at the King Edward VIII Hospital, built in 1936 and the teaching hospital of the university's medical school for 'Non-Europeans'. The hospital managed the delivery of 23000 African babies a year and, with 200 beds, was at the time the third largest such ward in the world. ${ }^{23}$

Crichton quickly rose to the top of his profession. He became a Fellow of the Royal College of Surgeons of Edinburgh in 1953 and a Fellow of the Royal College of Obstetricians and Gynaecologists in $1957 .{ }^{24}$ He was awarded the Blair-Bell Lectureship by the latter in 1965 for outstanding research and in 1967 won the Hamilton-Maynard medal for the best South African medical publication of the year, an article describing his method of repairing ureteric fistulae. ${ }^{25}$ In 1969 he became the external examiner for the Royal College of Obstetricians and Gynaecologists; this was in addition to the English-speaking South African universities and the University of Salisbury in Rhodesia (Zimbabwe). From 1967 until he left South Africa in 1974 he performed all sex-realignment operations (male to female) in Natal. ${ }^{26}$ At the time of his arrest in 1972 he was President of the Regional Council of the Royal College of Gynaecologists and Obstetricians in South Africa. ${ }^{27}$

Crichton was famous for his extreme self-confidence. As an Indian patient embarking on the process of sex reassignment said about Crichton, 'He had an unshakeable confidence

\footnotetext{
20 'Doctor Gets 5 Years, 34 weeks: Appeal Lodged in Rand Case', Daily News, 10 August 1949.

${ }^{21}$ Ruby G Sharp, 'Tribute to a Great Teacher', South African Medical Journal, 56, 23 (1979), 1059-74.

22 'Derk Crichton States' a document produced to prepare defence for Derk Crichton's 2nd trial, 2, Crichton Papers, op. cit. (note 11).

23 Testimony of Dr Derk Crichton in Durban Supreme Court. 'Crichton, Derk. Criminal Case: Procuring an Abortion (26 Counts)', Durban Archives Repository, TBD/RSC/LEER, 1/1211, (hereafter Crichton and Watts Trial Transcript), Vol. 3, 607-8.

24 'Derk Crichton States', a document produced to prepare defence for Derk Crichton's 2nd trial, 2, Crichton Papers, op. cit. (note 11).

25 Derk Crichton, 'Ureteric Injuries in Gynaecological Surgery', South African Medical Journal, 39, 29 (1965), 686-91.

26 'Crichton Gave Girl "New Chance in Life", Daily News, 30 May 1974.

${ }^{27}$ Crichton and Watts Trial Transcript, Vol. 3, 608.
} 
in what he was doing which seemed to boost the spirits of those he came in contact with' ${ }^{28}$ An Indian doctor, formerly a student of Crichton's, recalled, 'Derk Crichton was like a god to us, we would queue for his lectures which for us were like the Ten Commandments. He was so sure of his medicine that if he told us to treat a patient a certain way, regardless of what the textbooks said, we did it. . ' ${ }^{29}$ He was also infamous for his temper and inability to 'suffer fools'. ${ }^{30}$ Bongiwe Bolani, who worked as a nurse at King Edward VIII Hospital in the mid-1960s, remembers Crichton as arrogant and terrifying:

He was a horrible man. He always shouted at the nurses and doctors - everybody.... He was cruel. He put such terror in people. He screamed, he shouted, he humiliated us, made you feel like imbeciles. He had such a sense of his own importance. ... I was young then, so his effect on me was enormous. Other people, older white males, terrified me from that time for many years. It took a long time for me to get over it. Many people resigned and left because of him. ${ }^{31}$

But he was also deeply admired by at least some black medical students. One of Crichton's former students is Dr Sam Mokgokong, South Africa's first African gynaecologist and instructor in a medical school, and he recalls Crichton with huge affection, saying 'he's like a father to me, he took me up, he made me'. He says Crichton was colour-blind and 'even-handed' with his students, meaning he treated his white and black students the same. ${ }^{32}$ Even Bolani recalls Crichton urging black nurses to obtain further training so they could be promoted to higher positions. She 'took up this educational challenge' and eventually became a matron. ${ }^{33}$

At both Addington Hospital (for Whites and Coloureds in segregated wards) and King Edward VIII Hospital (for Africans), as well as in private practice, Crichton was constantly confronted with the effects of clandestine abortion, telling an audience in 1970, 'Were I a member of the Clergy I might say that abortion is my "daily bread"'. As he said in court, 'I know more about criminal abortions in Durban than anyone else - it would be extraordinary if I didn't'. ${ }^{34} \mathrm{He}$ estimated that during his eighteen years at King Edward VIII and McCord Zulu Hospital between 1954 and 1972 he had treated an astounding 40000 African women suffering the effects of illegal abortion - 'at least' one died every month. ${ }^{35}$ Some girls and women he treated had procured abortions on themselves but most had gone to untrained abortionists, the vast majority of which were what he called 'soap injectors' because they injected liquid soap into women's uteri, a dangerous method that often caused infection or death as a result of air or soap entering the blood stream. The method was popular with clandestine abortionists because it was relatively easy and could be employed in one visit. He estimated the soap-injection method killed one in every 200 women and left another 5\% sterile. In court in November 1972 he said that even 'in the last two or three days, we've had to do two hysterectomies for gangrenous uteri as a result

28 'Crichton Gave Girl "New Chance in Life", Daily News, 30 May 1974.

29 Cited in June Cope, A Matter of Choice: Abortion Law Reform in Apartheid South Africa (Pietermaritzburg: Hadeda Books, 1993), 56.

${ }^{30}$ Linda Redman, Crichton's former secretary, interviewed in Durban, 12 November 2009. She recalls Crichton had a 'very short fuse' and 'a temper', and would at times unleash his frustrations about his work on her; he once threw a vase at her. They are still friends today.

31 Noble, op. cit. (note 5), 180.

32 Telephone interview with Sam Mokgokong, 2 July 2011.

33 Janet Lea Twine, “'I'm Just an Ordinary Nurse": A Life History of Matron Bongiwe Bolani', (BA Honours thesis: University of Natal, Durban, 1997), 46.

${ }^{34}$ Crichton and Watts Trial Transcript, Vol. 3, 609.

35 Ibid. 
of soap injections' ${ }^{36}$ Complications from abortion were the number one issue facing his unit: in the first eight months of 1973, 934 cases of 'complicated abortion' were admitted to King Edward VIII, of which 354 had been septic. He said, 'We can only admit the hard core of complicated abortion cases because of restricted bed space'. ${ }^{37}$

As a consequence of this experience Crichton concluded that the law on abortion was unrealistic and outmoded. In July 1970 he gave a speech on abortion at the University of Natal where he declared:

[T]he struggle for emancipation from this bondage (of legal and religious condemnation), to have a fertility franchise for women constitutes one of the major challenges of our time. My crusade for this goal is inspired not only ideologically, but also as a result of my personal contact with the human tragedies which result from our present system, especially the consequences of illegal abortion.

To Crichton 'this problem assumes proportions which render a fight for its eradication an inescapable duty'. True to form, therefore, he did not keep his opinion to himself. Beginning in the late 1960s he began calling for law reform and very quickly became the country's most visible and outspoken medical advocate of abortion on demand, telling an audience in 1970 'we must remain dauntless that there can be no compromise in this struggle to achieve the ultimate ideal that every woman should be the captain of her womb' ${ }^{38}$ A radical in a conservative profession, he became a self-described 'crusader' for women's right to control their reproductive capacity. Just a few months before his arrest Crichton called for abortion law reform at the annual meeting of the South African Society of Obstetricians and Gynaecologists (SASOG). ${ }^{39}$

\section{James Watts}

James Watts, aged 41 at the time of his arrest in 1972, was a complex man with a vastly different background from Crichton's. Born in Cape Town in 1931, Watts grew up on a farm in Kraaifontein. His mother had once been a schoolteacher in Namibia but was a stay-at-home mother when he grew up; his father had lost his business making refrigerator cabinets during the Depression after which his parents managed a convenience store on their farm. Watts had eight years of public schooling and moved to Durban in 1953 where he worked for five years as a fire fighter on the railways. In 1961 he started working for Shell Oil as a refinery operator. Watts says that while working on the railways a coworker urged him to do more with his life. 'He said to me "you must educate yourself, read Reader's Digest from front to back". An extremely intelligent man, Watts would undoubtedly have been a professional of some kind, probably a doctor or a veterinarian, if he had been able to pursue an education. Since tertiary education was impossible, biology and physiology became his hobbies. His motivation for becoming an abortionist appears very similar to that of other excellent clandestine abortionists, such as the American Ruth Barnett who had an incredibly successful and lucrative abortion clinic in Oregon from 1918 to 1968. Barnett's biographer Rickie Solinger, writes that her 'restlessness, her intellect, and her belief in her own capabilities' fuelled her desire to become a firstrate abortionist. ${ }^{40}$ Watts was an independent thinker and seems to have been instinctively

36 Ibid., 609-12.

37 'Crichton Tells of Mission', Daily Mail, 21 May 1973.

38 Derk Crichton's James Louw Memorial, Symposium Address to University of Natal Medical School, July 1970, Crichton Papers, 1, 3, 9-10, 13 (hereafter Crichton Lecture).

39 'Doctor Calls for Abortion Law Reform', Rand Daily Mail, 14 April 1972.

${ }^{40}$ Solinger, The Abortionist, 8. 
subversive (though never interested in politics), and his contempt for apartheid morality combined with his sharp intellect, fascination with biology, and ambitiousness made it easy for him to live a double life as an employee of Shell and a 'criminal' abortionist.

Watts performed his first abortion in 1963 seemingly out of intellectual curiosity. A friend whose girlfriend was pregnant was looking for an abortionist and Watts told him he should just do the abortion himself. But his friend refused, 'so', Watts recalls, 'I did it myself'. ${ }^{41}$ He studied as much as he could beforehand, looking for relevant medical literature in the library, bookstalls and at CNA (a South African chain of bookstores), and claims there were 'mountains of literature available, there have been mountains of articles and books on abortion dating back to Plato'. After performing his first abortion his friend's sister came to him for the procedure. 'After that it became easier' and thus began his career as an abortionist.

Watts became a highly skilled and meticulous abortionist, which is why Crichton referred the teenagers and young women needing abortions to him (see below); during his trial doctors said they were 'amazed' by his skilfulness. ${ }^{42}$ 'I was very sterile conscious', he said, knowing there was the possibility of infection: while growing up in the Cape he knew abortionists who used the syringe method, mostly retired white nurses, and girls who became ill afterwards. He said that, like his clients, he was always nervous when performing abortions because he was intensely aware of what could go wrong and knew there was always the possibility that he could be arrested. Determined to avoid medical and legal trouble, from the beginning he only used the far safer method of inserting sterilised catheters. He used urinary catheters, bought from a contact who supplied pharmacies, and always 'shaved girls anywhere where hair could touch the catheter to prevent infection, or else told the girls to shave themselves'. He had his own supply of antibiotics for patients who could not obtain any (obtained from the same contact), sterilised his equipment beforehand, and sealed off catheters after insertion with sterile cotton wool dipped in Hibitane (a disinfectant). He also told girls to obtain a medical follow-up, instructing them to wait until there was significant bleeding (so that the miscarriage could not be stopped) and then go to a doctor for a dilation and curettage (D\&C) to ensure the abortion was complete and avoid infection. Watts' 'cut-off point' for performing abortions was four months of pregnancy because after that abortions 'are more dangerous'.

Watts is an intriguing figure. He was a self-taught abortionist wholly unlike the stereotype of the unscrupulous and dangerous operator often invoked by doctors and liberal feminists furious about the horrific consequences of criminalising abortion, a negative image reinforced by the occasional prosecution of untrained abortionists, usually women, after the deaths of their clients led to discovery. ${ }^{43} \mathrm{He}$ openly admits he was in 'the abortion business' for money and added that he saw no difference in that regard between himself and trained medical doctors like Crichton. Indeed, Watts took pride in his professionalism and considered himself an ethical, non-judgmental practitioner; even Crichton referred

${ }^{41}$ Unless otherwise indicated, the quotations are of Watts' comments made during my interview with him at his home in KwaZulu-Natal on 2 December 2009.

42 'Doctors Amazed By Abortionist James Watts', Sunday Express, 10 December 1972.

43 For example, in 1972 Engela Catarina Moller, a 42-year-old housewife, was found guilty in Durban Regional Court of the charge of culpable homicide and was sentenced to prison for eighteen months; nine months were conditionally suspended for three years. The woman who died, Joy Botha, had first gone to Crichton for an abortion but he had refused. 'Woman sentenced for Attempted Abortion', Daily News, 1 November 1972; 'Abortion Death: Woman Gaoled', Cape Times, 1 November 1972; 'Crichton Tells How Woman Died at Abortionist's Hands', Natal Mercury, 25 May 1973. 
to Watts' 'patients' at one point during the trial (see below). As Watts told the court, 'What motivated me was to protect girls I have helped from going to other abortionists that use syringes and knitting needles as I have often seen terrible consequences from their work. . . I I knew somebody had to help them' ${ }^{44}$ He says he performed abortions to help 'good girls' who were in trouble, he said, 'bad girls' knew how to prevent pregnancy. ${ }^{45}$ (Watts himself was a father; at the time of his arrest he was married with two sons aged 13 and 15.) Watts performed abortions on 'all kinds of women'. Most clients were white, about $60 \%$ Afrikaans and $40 \%$ English. Although he did occasionally do abortions on Indian and Coloured girls - 'Pregnancy knew no colour barrier, they were all girls in need' - segregation under apartheid and his acceptance of it ensured he mainly came into contact with other whites. Most were teenagers and single young women in their early twenties. His clients generally paid with cash, although he accepted cheques, and he consulted his own version of a sliding scale that reflected his moral worldview when charging fees. For most girls and women he charged the same as Crichton, i.e. usually between R60 and R80, which he considered fair because in addition to being an expert who deserved to make the same wage as a doctor he was operating entirely outside the law. He says he charged nurses and prostitutes less and sometimes nothing at all because as working women their jobs were at stake. He also charged less, if anything, to help police officers' girlfriends, undoubtedly because it was in his interest to have friendly relations with police.

Watts' reputation reached women and doctors beyond Durban, and word-of-mouth, as was so commonly the case with abortionists willing to break the law, was the means by which information about him circulated. He says himself, "the more I did, the more my reputation spread by word of mouth, and several doctors, some as far away as Cape Town, referred some patients in need to me'. The number of clients varied from a few per month to a few per week; requests often came after holidays. One teenager learned of Watts from a woman she met at the local movie theatre. Another client, from East London, said a friend-of-a-friend from Durban told her about him. He also had a contact in South West Africa (Namibia) 'who flew in a few girls. One was an Afrikaans girl whose father was a preacher; she said her dad would kill her if he found out she was pregnant. She threatened to kill herself by jumping off a building if I didn't help her so I did not have much choice.' He never asked clients for personal information and kept no records but recalls a host of dramatic stories. For example, 'One Afrikaans woman flew up from Cape Town and we met in a car park as arranged and she was wearing a veil. She did so the whole time. She had an Afrikaans accent. I never interrogated or questioned their identity [sic], I did not wish to embarrass them. I could only speculate, but (she was) definitely upper bracket.' He reports that sometimes it was more affordable or convenient for women to bring him to them. He was flown to Cape Town and Johannesburg by clients and went twice to Kruger National Park to perform abortions on women ostensibly on holiday.

Watts never discussed abortion in feminist terms as a woman's 'right' - there was no feminist movement in South Africa in the 1960s and Watts had no contacts outside South Africa. However, evidence given by teenagers and young women conveys the image of a diligent and sympathetic practitioner. For example, one teenager testified that she came to Durban alone for an abortion and Watts met her at her hotel to perform the procedure. However, the hotel did not have hot water, 'So he said, "Oh well then he would have to

44 'Statement by James Watts to Mr. Justice James', 14 November 1972, 3-4, Crichton Papers, op. cit. (note 11).

45 "'I Acted for the Girls" Sakes - The Parents Are To Be Blamed, Not Me': Abortion - Watts Tells His Story', Natal Mercury, 9 December 1972. 
take me to his house as we had nowhere else to go", and drove her to his home where he sterilised his equipment, took her to his bedroom and inserted the catheter. Afterwards his wife gave her a cup of tea before he drove her back to her hotel. The next day he picked her up and drove her to a clinic for a D\&C 'where he did all the talking for me'. After her procedure she took a taxi to the hotel where she was met by Watts who stopped by to 'see how I was, just as I arrived back. . . . He came upstairs with me to my bedroom, and he had a drink, and he stayed for a little while and then he left'. ${ }^{46}$ He would commonly allow girls to stay overnight at his downtown flat purchased for his practice while they waited to miscarry and sometimes had drinks with the girls and/or their boyfriends after inserting the catheter. One boyfriend said the atmosphere in Watts' flat was 'very friendly'. A young woman described how Watts prepared his instruments and inserted a catheter, then 'Afterwards I got dressed and my boyfriend and Mr. Watts had another drink together while I did exercises in the room'. ${ }^{47}$ (She did not explain what kind of exercises.) Occasionally Watts impersonated girls' fathers or boyfriends when calling doctors to schedule D\&Cs ${ }^{48}$ and at times he adopted the role of moral guide, 'strongly' advising one young woman, for example, against marrying a young man who admitted impregnating another girl. ' $\mathrm{He}$ said that I shouldn't marry a man like that', she testified in court. ${ }^{49}$ In another case a boyfriend reported returning to Watts' flat after the catheter had been inserted and found Watts waiting for him. Then, seemingly empathising with the girl and expressing what he imagined to be her feelings, Watts made an extraordinary statement: 'What us poor women have to go through for you men' ${ }^{50}$ During the trial Watts' lawyer asked a mother who had arranged her daughter's abortion if she was satisfied with Watts' treatment and she replied, 'I felt he had her welfare at heart. He gave her the best care possible. Prof. Crichton and Jimmy were the best'. 51

\section{The Crichton-Watts Connection}

As a rare outspoken liberal on the controversial issue of abortion Crichton attracted a great deal of publicity for his radical views. Consequently teenagers and young women from around the country approached him for abortions. As he put it, his public comments accounted for the 'flocks of young women' coming to him for help. 'Since I have started lecturing. . . on the subject', he said, 'the numbers have swelled tremendously'. ${ }^{52}$ By the early 1970s he was confronted 'almost daily' with 'the unmarried girl with the unwanted pregnancy pleading for abortion'. In addition, doctors unwilling to perform abortions referred their pregnant patients to him, and he often helped young women 'when other doctors have refused to do so. I have often had a great deal of trouble getting other doctors to agree that an abortion is necessary'. ${ }^{53}$ (Two of the teenagers who testified said they were told about Crichton by their family doctors.) Crichton did not relish the flood of young women seeking abortions for he was already 'grossly overworked' and did not want to put his career in jeopardy. He therefore repeatedly told girls that doing abortions was 'out of

${ }^{46}$ Crichton and Watts Trial Transcript, Vol. 1, 105-6.

47 'Abortion Evidence', Natal Mercury, 23 November 1972.

48 'Statement by James Watts to Mr. Justice James', 14 November 1972, 2, Crichton Papers, op. cit. (note 11).

${ }^{49}$ Crichton and Watts Trial Transcript, Vol. 1, 86.

50 Ibid., 134.

51 'Girl's Mother Sobs In Court', Natal Mercury, 25 November 1972.

52 Crichton and Watts Trial Transcript, Vol. 3, 613.

53 'Abortion Case Judgment Surprise', Natal Mercury, 6 December 1972. 
the question' regardless of the amount of money they offered. Yet he realized girls were determined to have an abortion no matter the risks, as many subsequently confirmed in court. 'Many of them were in tears and. . . averred that they would commit suicide if a solution could not be found. I usually experienced frustration in finding that most of what I was saying to the patients was "passing in one ear and out of the other". 54

Knowing full well from grim experience that girls would have no difficulty in finding abortionists - 'I was terrified that they would go to a soap injector' 55 - he 'felt it my duty to safeguard them to the best of my capabilities' ${ }^{56}$ He devised a system that would assist the girls and, he believed, shield him from prosecution. The common law on abortion prohibited a doctor's induction of a miscarriage but allowed for treatment in cases of miscarriages already begun. ${ }^{57}$ So he started to unofficially refer girls to abortionists whom he knew used sterilised catheters, what he called the 'tube inserters', to initiate a miscarriage, along with firm instruction that they should visit a doctor immediately afterwards for a D\&C in order to ensure that the abortion was complete. Most tube inserters were Indian but, much to his irritation, the majority of white patients preferred white abortionists because they thought Indians were 'unclean'. Regardless of his assurances, most white girls wanted a white abortionist, so he referred them to Watts.

Watts was brought to Crichton's attention in 1971 by nurses at Addington Hospital. They told him that a man named Watts was a careful and effective abortionist who took precautions to avoid infection, such as shaving pubic hair, and whose patients never fell ill. Crichton explained in court, 'Mr. Watts' patients told me that he inserted a sterile soft rubber catheter with extreme gentleness and great regard to sterility'. ${ }^{58} \mathrm{He}$ said 'I've never seen a case (of Watts') go wrong, ${ }^{59}$ in fact his 'cases seem to be doing a jolly side [sight] better than the others. And we noted this over the months that these patients did not seem to have the complications the others had' ${ }^{60}$ In spite of never meeting and their vast differences in class and social status, the two men developed a kind of working relationship. Crichton gave girls Watts' telephone number, usually a prescription for antibiotics to take in advance of the procedure to minimise the risk of infection, and advice to return to him or another doctor for a D\&C after Watts had induced bleeding. Conversely, girls who first contacted Watts were sent by him to Crichton for a prescription for antibiotics before returning to him for the miscarriage, after which he insisted they return to Crichton for a D\&C. Girls in court repeatedly gave confirmation of this two-step procedure. Crichton was certain this method protected him; in court he said confidently, 'I always covered myself' by not inducing the miscarriage. ${ }^{61}$ Indeed, he was so assured of his safety that he kept case records with detailed notes on patients that, ironically, would ultimately help the prosecution convict him. His confidence was a combination of his naturally optimistic outlook, naïveté, and arrogance derived from his privileged status in

\footnotetext{
54 'General review of Professor Derk Crichton's Account of his Treatment and Handling of the 27 State witnesses whom the State Claims Jimmy Watts criminally aborted (or tried to) and Professor Derk Crichton was guilty of acting in concert with him', 2, Crichton Papers, op. cit. (note 11).

55 Crichton and Watts Trial Transcript, Vol. 3, 618.

56 Ibid., 637.

57 'Crichton Tells How Woman Died at Abortionists hands', Natal Mercury, 25 May 1973.

58 'Preliminary facts to be taken into consideration in defence against the accusation that I Professor Derk Crichton acted in conspiracy with J.W. Watt to procure abortions', 1, Crichton Papers, op. cit. (note 11).

${ }^{59}$ Crichton and Watts Trial Transcript, Vol. 3, 682.

${ }^{60}$ Ibid., 617.

${ }^{61}$ Ibid., 662.
} 
his profession and society. When warned by a colleague that he would get into trouble if he continued 'referring' girls to abortionists he replied, 'I've got nothing to worry about' ${ }^{62}$ His wife reported that he was 'thoroughly shocked' when the police arrived at his home early one morning to arrest him. ${ }^{63}$

For girls and women, the Crichton-Watts system was safe, rapid and relatively respectful of their privacy and dignity. In contrast, staff at hospital casualty departments were often prying, judgmental, and sometimes openly hostile to girls and women wanting help with incomplete or botched abortions. For example, women who went to the Addington Hospital casualty department after abortionists had induced miscarriages, would spend 'many hours' waiting for a D\&C, during which time they were frequently questioned 'in detail' about their abortions. ${ }^{64}$ Girls told Watts that they received 'rough treatment' and were 'cross examined' there, and Crichton said girls complained that the nursing staff and doctors embarrassed them by gossiping amongst themselves about their private lives. ${ }^{65}$ In fact, he said girls who were miscarrying 'refused with increasing frequency' to go directly to Casualty at Addington Hospital and would instead contact him directly to arrange their D\&Cs.

\section{The Police Investigation}

At the beginning of 1972 the police targeted Crichton for prosecution; ultimately Watts became significant to authorities only because of his association with Crichton. It is unclear how, precisely, the case against Crichton began. It is certain that an investigation into an 'alleged country-wide abortion network' began in $1969 .{ }^{66}$ At some point the Natal Provincial Council conducted an investigation into abortions being performed in provincial hospitals and handed their findings to the Attorney-General, who in turn notified the Durban police who apparently did not get very far with their investigation. ${ }^{67}$ Kobus Visser, chief of the Criminal Investigation Department (CID) in Durban, was determined to uncover clandestine abortion, however, so he sent out a call around the country for an officer to take charge of the investigation and Sergeant Dan Matthee (b. 1925) was hired. In a recent interview Matthee claimed the Minister of Health himself was responsible for targeting Crichton (though he would not say which one). He said the minister had been at an international conference where Crichton had spoken out against South Africa and as a consequence he wanted 'something done'. ${ }^{68}$ The story is plausible because the NP was intensely conscious of international criticism of South Africa. Since 1960, the year of the Sharpeville Massacre when police shot at least sixty-nine unarmed African protesters (many in the back as they were fleeing from police attack), the United Nations had repeatedly censured South Africa for its racist policies and called for cultural and economic sanctions. If Crichton was openly criticising South Africa overseas it is entirely believable, given the regime's vicious retaliation against previous critics, the NP would

\footnotetext{
62 Susan Pohl-Crichton, interviewed in Durban, 12 November 2009.

63 Telephone interview with Susan Pohl-Crichton, 31 May 2008.

64 'General review of Professor Derk Crichton's Account of his Treatment and Handling of the 27 State witnesses whom the State Claims Jimmy Watts criminally aborted (or tried to) and Professor Derk Crichton was guilty of acting in concert with him', 3, Crichton Papers, op. cit. (note 11).

65 'Statement by James Watts to Mr. Justice James', 14 November 1972, 3, Crichton Papers, op. cit. (note 11).

66 'Two Doctors Face Abortion Charges', Natal Mercury, 22 June 1972.

67 'Abortions - Top Doctor Detained', Daily News, 21 June 1972.

${ }^{68}$ Dan Matthee, interviewed in Durban, 12 November 2009.
} 
take revenge upon him at home. ${ }^{69}$ What is certain is that convicting a highly respected doctor like Crichton for providing abortions would be a means by which to instil fear into the hearts of other doctors and thereby stem white young women's access to medical abortionists (discussed further below).

The state dedicated enormous financial and human resources to gather evidence against Crichton. Matthee spent about a year investigating him, reported only to Visser, had 'carte blanche' and apparently unlimited funds, for ultimately he and his staff took thousands of witness statements. ${ }^{70}$ He proved to be as effective as Visser (and his political superiors?) had hoped, and as a consequence of his investigation he earned the nickname 'abortion buster' in the press. ${ }^{71}$ According to Crichton's allies Matthee was obsessed with convicting Crichton, a contention that Watts strengthened in a statement to the trial judge in which he said Matthee threatened to

... 'put the screws on me' unless I agreed to incriminate Prof. Crichton. ... I have been terrorised by Major Mathee [sic] that he will ensure that I receive a long jail sentence unless I give him a statement according to his instructions. . . Consequently I have lost confidence in the impartiality of the justice of the Court which is to try me. $^{72}$

In addition to his extreme dedication to his job as a police officer, Matthee's fixation on Crichton was likely fuelled by class and ethnic resentments that have genealogies dating back to the South Africa War (1899-1902) and the subsequent enmity between English and Afrikaans South Africans. Matthee came from a 'poor white' Afrikaans family in De Poort, a government settlement town in the Cape, whereas Crichton came from a distinguished English-speaking family of means. Matthee explained his pursuit of Crichton thus: 'I like challenges, especially when it comes to people with high qualifications and many letters after their last names'. He acknowledged that Crichton had a reputation for being an excellent doctor and said even his own sister had visited him (not for an abortion) but he found the man 'arrogant'.

Matthee examined medical records to find patient names and dates of suspect procedures. He directed hospitals and nursing homes in Durban to check their records and report procedures that could have been abortions, and then interviewed doctors and operating theatre nurses who assisted or witnessed Crichton's operations. At least one nurse who worked at St Augustine's Hospital described a number of Crichton's cases to the Matron as 'suspicious'. Crichton told his lawyer that the nurse probably did so 'out of annoyance at my "ticking her off" 'by calling her in to work in order to attend to a young woman in need of a D\&C. He also admitted berating the nurse for her 'inefficiency and obstructionism', which probably annoyed her further; in hindsight Crichton would have been wise to avoid alienating nurses, the very people who knew better than most about his abortion-related activities. (According to Watts, it was also a nurse who alerted Matthee to his involvement with Crichton.) Next Matthee travelled around the country locating and interviewing girls and women. In total, the police contacted 'at least 2000 suspected cases' whose names and addresses were found in hospital records, and drew up

\footnotetext{
${ }^{69}$ In 1950 the NP banned the South African Communist Party and in 1960 the African National Congress (ANC) was banned; both were opposed to apartheid. In 1964 Nelson Mandela and other leaders of the ANC were convicted of sabotage and sentenced to life imprisonment. Occasionally the NP regime assassinated critics of apartheid that had become dangerously influential, such as Steve Biko in 1977 while in police custody, and Ruth First in 1982 while in self-imposed exile in Mozambique.

${ }^{70}$ Dan Matthee, interviewed in Durban, 12 November 2009.

71 'Major Matthee Continues Investigating Abortion Racket', Daily News, 15 December 1972.

72 'Statement by James Watts to Mr. Justice James', 14 November 1972, 1, Crichton Papers, op. cit. (note 11).
} 
a list of 400 women to be 'closely questioned' ${ }^{73}$ In court he described how the girls were 'shocked' to receive telephone calls from local police asking them to come to the station for an interview with him.

Witnesses described having been bullied by Matthee into giving evidence. One said she was afraid of Matthee and that he had not allowed her to read over her statement. Watts reports that one girl telephoned him and said 'Matthee had threatened that unless she testified her father would lose his (government) job', ${ }^{74}$ a claim also made in court by Crichton's defence. ${ }^{75}$ The boyfriend of the girl caught leaving Watts' building on the evening of his arrest said Matthee threatened to 'lock him up' unless he gave a statement. When called in for an interview he brought a friend who was an articled law clerk with him to the police station. Matthee told the boyfriend he considered him an accomplice and wanted him to make a statement but his friend advised him not to unless Matthee gave him an indemnity from prosecution. This angered Matthee who allegedly told the boyfriend, 'I will lock you up and I will keep you locked up until you make a statement' ${ }^{76}$ After he threatened the young man that the Attorney-General might charge him as an accomplice he admitted that he helped his girlfriend obtain an abortion and signed a statement. ${ }^{77}$ Matthee admitted in court that he took '98\%' of witnesses' statements himself and even re-interviewed witnesses who had been interviewed by other officers. ${ }^{78}$

Watts was arrested first. On 9 June, 1972 three plain clothes officers, one of which was Matthee, watched a young couple enter Watts' building at about 7:00 p.m. When they emerged an hour later the police arrested them and took the couple back to Watts' flat, which was searched, and Watts was arrested. (The young woman was taken to a district surgeon who removed the catheter Watts had just inserted, which was then taken into evidence. ${ }^{79}$ ) Crichton was arrested on the morning of 21 June 1972, at the same time that a colleague of his, Dr Angini Maharaj, was also arrested on suspicion of procuring abortions. The police seized their medical records and then compared the names found in Crichton's and Maharaj's records to those listed in hospital and nursing home records as having had D\&Cs.

In June 1972 Matthee told the Attorney-General for Natal, N.C. Masters, 'I thought I had a very strong case', and Masters decided to hold not one, but two trials for Crichton, the first to include 'the easy witnesses who had given affidavits; the second trial. . the less reliable witnesses and some (who) wouldn't talk'. The first trial included Watts and took place in November and December 1972. The second trial, at which he was tried alongside Maharaj, took place in Durban Regional Court in March 1973, an event I discuss elsewhere. ${ }^{80}$ (During the second trial Dr Maharaj reported that she had 'refused an offer of indemnity from prosecution if she gave evidence against Prof. Crichton because of her

\footnotetext{
73 'Two Doctors Face Abortion Charges', Natal Mercury, 22 June 1972; Abortion: Major Denies Threats, Daily News, 28 November 1972.

74 James Watts, interviewed at his home, KwaZulu-Natal, 2 December 2009.

75 'Girl Denies Evidence Was Influenced', Daily News, 22 November 1972.

76 'Abortion: Major Denies Threats', Daily News, 28 November 1972.

77 'Lock-Up Threat to Boyfriend Denied by Major', Natal Mercury, 28 November 1972.

78 Transcript Crichton and Maharaj trial, 517, Crichton Papers, op. cit. (note 11).

79 Testimony of District Surgeon Gian Carlo Dini, Crichton-Watts Trial Transcript, Vol. 3, 503-4; letter from Dr. D.A.G. Barford to Medical Superintendent, Addington Hospital, 12th June 1972. Exhibit XX in Crichton and Watts Trial Transcript, Vol. 1; 'Major Tells of Arrest of Watts', Natal Mercury, 28 November 1972; Major Tells of Watch on Watt's Flat, Daily News, 28 November 1972.

80 The second trial is discussed in Susanne M Klausen, Abortion Under Apartheid: Nationalism, Sexuality and Women's Reproductive Rights (Oxford and New York: Oxford University Press) forthcoming.
} 
loyalty and high regard for him' ${ }^{81}$ ) Crichton's lawyers and friends believed at the time, and still do, that the reason for holding two trials was to drag out legal proceedings for as long as possible in order to cause him maximum financial and professional hardship; a reasonable conclusion in light of the significant time and money it cost him to mount two legal defences while attempting to maintain his practice and teach at the University of Natal.

\section{The Prosecution}

The state charged Crichton and Watts, with the following:

Having been approached to procure an abortion, Accused No. 1 recommended that someone else had to start the bleeding in the private parts of each female concerned, for which purpose he referred her to Accused No. 2 , who then caused the bleeding with a catheter. A dilatation and curettage was performed by Accused No. 1 subsequently to complete the abortion.... It is unknown to the State when the common purpose was formed or whether there was an express agreement between the two accused, but it can, however, be inferred from their conduct that there was a common purpose and that they acted in concert. ${ }^{82}$

The prosecution had a powerful case. The girls and young women who had procured abortions were considered accomplices along with the people who had helped them boyfriends, brothers, girlfriends, parents - and all were pressed into testifying in exchange for indemnity from prosecution. The twenty-six young women called to testify had been between the ages of 17 and 23 at the time of their abortions, all unmarried. About half were English-speaking South Africans and half were Afrikaans-speaking. Crucially, all were white and it was their whiteness that provoked authorities to intervene in the clandestine abortion industry in the first place. As Crichton explained in court, criminal abortion was the 'major problem' in his unit at the King Edward VIII Hospital, ${ }^{83}$ which served Africans and treated the greatest number of septic abortions in South Africa at the time. ${ }^{84}$ Yet there was never an attempt by police to investigate the extensive, deadly abortion industry in relation to black women. The NP was concerned only with white girls, suggesting that, as signifiers of whites' supposedly superior morality, they were expected to be chaste and obedient.

The trial was a popular spectacle. Every day both the 'White' and 'non-White' courtroom galleries were 'packed' with spectators, and all the national newspapers as well as the local press covered in voyeuristic terms what was called 'South Africa's most sensational abortion trial'. The young women were objects of fascination and the press tried to read their appearance for signs of immorality; one newspaper described many of the girls as 'attractive mini-skirted young women'. ${ }^{85}$ Indeed, the courtroom had what Solinger, in her study of the prosecution of American abortionists, calls a 'cryptoporno atmosphere', for two reasons. First, the spectacle was made sexually tantalising by Crichton himself - a handsome, athletic, dapper man of 52 whose stylish attire was regularly noted by reporters. Furthermore, Crichton, already twice divorced, was regularly accompanied to court by two much younger, unmarried women, his 'attractive' secretary

\footnotetext{
81 'Abortionists Fined: Court's Sympathy', Daily News, 4 August 1973.

82 'In the matter between: the State and (1) Derk Crichton, Accused No. 1 and (2) James Watts, Accused No. 2', 1-2, Crichton Papers, op. cit. (note 11).

${ }^{83}$ Crichton and Watts Trial Transcript, Vol. 3, 609.

84 'Patients "Sent for Advice", Daily News, 22 May 1973.

85 'Trial the World Is Watching', Sunday Tribune, 26 November 1972.
} 
Linda Redman and his live-in girlfriend Susan Pohl, age $26 .{ }^{86}$ The young women's presence, photographed and commented upon in the press, heightened the fascination with Crichton and the trial generally. The visibility of middle-aged, respectable Crichton, a divorcee and father of three children, living with a very beautiful woman half his age added an exotic cache of sin, pleasure and glamour to the situation. Moreover, Crichton's defiant, thoroughly unrepentant attitude during the trial enhanced his presence and audience fascination. For example, when asked by the prosecutor, Haasbroek, why he did not inform the police of the names of criminal abortionists he knew of, he said,

I do not think it is my duty to act as a policeman. Haasbroek: Yes but you must have known that the police were investigating matters of this type. They were trying to get information. Crichton: If they wanted information they could have come and asked me. Haasbroek: But out of your own accord you wouldn't give them the names? Crichton: I do not regard it my duty as a doctor to report to the police every time I find that a patient has had an abortion done which is illegal. ${ }^{87}$

Second, the prosecution humiliated the girls with embarrassing questions about their sex lives, bodies and abortions. Of an 18-year-old the judge asked 'whether she had had intercourse with her boyfriend' (she made the unsurprising admission that she had). The state's lawyer Schutte asked a girl if there 'was there anything irregular about your breasts' before she saw Watts, and continued: 'Now what did Mr. Watts do with the instrument? Answer: He inserted it in me, he put it inside me. Schutte: Where did he insert this thing, you needn't be afraid. A: I don't know how to say it. Q: Judge: Did he insert it between your legs into your private parts? A: Yes' ${ }^{88}$ Of another young woman the state prosecutor, Haasbroek, asked questions about the size of her breasts prior to the abortion. ${ }^{89} \mathrm{He}$ asked yet another to 'Describe the abortion from the beginning. Answer: He didn't shave me, he just cut - cut the pubic hair with scissors. Haasbroek:Yes?Answer:And then he. . ' but just then Justice James intervened and asked, 'I'm sorry, what did he cut with the scissors?' and Haasbroek replied, 'The pubic hair'. Justice James: 'Oh your pubic hair' ${ }^{90}$ Of a teenager who was 17 at the time of her abortion Haasbroek asked, 'What did he (Watts) actually do with the tube and the wire? Answer:He inserted the tube and wire into me. Haasbroek: Yes, where? Answer: Into my Virginia [sic] ${ }^{91}$ Many answers were so similar in phrasing that the defence accused the prosecution of coaching the young women in order to illustrate that a 'system' had been devised by Crichton and Watts. ${ }^{92}$

The magistrate presiding over the second trial noted that the girls 'testified under extreme stress and strain and were understandably nervous. They were subjected to lengthy, embarrassing, repetitive and sometimes torrid cross-examination' ${ }^{93}$ Some young women were so distressed by the questions they buckled on the stand. For example, one 19-year old girl at the first trial, 'broke down in the witness box, sobbing loudly' when asked to describe the abortion and, with 'her head bowed... was led from the packed court to compose herself'. ${ }^{94}$ There was an exception. One young woman was impervious to

86 'Crichton Found Guilty', Daily News, 7 December 1972; 'Abortion: Crichton Fined R500, Watts Gaoled', Natal Mercury, 8 December 1972. Derk and Susan remained together, marrying in 2007 at the ages of 86 and 60.

${ }^{87}$ Crichton and Watts Trial Transcript, Vol. 3, 636.

88 Crichton and Watts Trial Transcript, Vol. 1, 230 and Vol. 2, 245.

${ }^{89}$ Ibid., Vol. 2, 246.

90 Ibid.

91 Ibid., Vol. 1, 10.

92 'Advice on Evidence', 6 November 1972, 1, Crichton Papers.

93 Magistrate judgment in Crichton and Maharaj trial, 3579, Crichton Papers, op. cit. (note 11).

94 'Girl Witness Breaks Down at Abortion Trial', Daily News, 23 November 1972. 
intimidation, and rebellious, even surly while giving testimony. She was unforthcoming and repeatedly claimed she could not remember details about the abortion, in the process angering Crichton's lawyer, Shaw, who subjected her to increasingly aggressive questioning. Clearly unafraid, her tussle with Shaw was entertaining to observers who sometimes laughed in court as they witnessed the exchange between the two. ${ }^{95}$

Significantly, in previous as well as contemporaneous trials of medical abortionists, white girls and women were spared public shaming. In 1949, during the preparatory inquiry in advance of the prosecution of Buchner and his employees working at the Castle Mansions abortion clinic (mentioned above), the identity of girls and women had been protected lest they be embarrassed or even 'ruined' by public exposure. Displaying great concern for the women's welfare the prosecutor had explained why the inquiry should be held in camera:

The Crown will be calling women to give evidence, some of them unmarried, some married, but their husbands do not know of any operation. ... In certain cases these women would be seriously prejudiced, and perhaps their whole lives would be ruined if the facts were made public. These women would be required to testify about intimate sexual details, and they have told the inquiring officer of their extreme reluctance to testify in open Court.

The magistrate agreed, saying with apparent sympathy that otherwise witnesses might not give evidence with necessary frankness. ${ }^{96}$ During the actual trial, at which an astonishing fifty-eight women testified, there had been a publication ban placed on their names and personal details (although this time the press could attend court on condition they protect the women's identity); the Court even provided female shorthand writers to transcribe evidence to spare the women discomfort. ${ }^{97}$ And in July 1972, just four months before Crichton was prosecuted, an Afrikaans doctor named Jurgen Backeberg was prosecuted on sixteen counts of procuring abortion and one charge of culpable homicide after the death of a 14-year old girl following an abortion, and during his trial teenage girls and young women gave testimony behind closed doors to protect their privacy. ${ }^{98}$ Clearly, the Crichton-Watts trial was exceptional, a show trial aimed at buttressing apartheid culture by disciplining both 'wayward' young white women and liberal members of the medical profession.

On judgment day, December 7, the court was 'sardine-packed' hours before the judgment was due to come down. ${ }^{99}$ 'Dozens of fashionably-dressed women - ranging from teenage to elderly... spilled over the galleries and stood in the aisles' to hear Justice James' verdict. ${ }^{100}$ One newspaper described how 'Spectators, White and Black, crammed every available space in the galleries and overflowed into the aisles. City workers in safari suits and overalls rubbed shoulders with elegantly dressed elderly women - some of whom have been present throughout. . . the trial. ${ }^{101}$ Crichton and Watts bore the stress of waiting for the verdict very differently; indeed they were a study in contrasts, with each man's

95 Crichton and Watts Trial Transcript, Vol. 1, 151-200.

96 'Magistrate Allows Women's Evidence to be Heard in Camera', Daily News, 17 January 1949; 'Allegations of Abortion against Two Rand Doctors and Women: Press and Public Barred from Court', Natal Witness, 17 January 1949.

97 'Rand Abortion Allegations: Married Women Give Evidence in Court', Natal Witness, 20 January 1949; 'Fiftyeight Women Assemble to Testify for Crown', Daily News, 16 May 1949.

98 'Doctor Faces Abortion Charges', Daily News, 27 July 1972; 'Death Court Hears of Abortions in Luxury Home on Banks of Vaal', Sunday Tribune, 30 July 1972.

99 'Court Full For Abortion Verdict', Daily News, 7 December 1972.

100 'Abortion: Crichton Fined R500, Watts Gaoled', Natal Mercury, 8 December 1972.

101 'Crichton Granted Leave To Appeal', Daily News, 8 December 1972. 
demeanour reflective of his class position and status in society. Crichton appeared cheerful and confident: 'smartly dressed in an olive green suit, an orange shirt and matching tie, [he] chatted happily with his lawyers and smilingly acknowledged the many nods of encouragement he received from spectators'. Another newspaper reported, 'Easily the most smartly dressed man present was Professor Derk Crichton, in vivid orange shirt and tie and an avocado green suit. ${ }^{102}$ Conversely, Watts, who had no faith whatsoever in the justice system, was extremely nervous. While awaiting the judgment he requested permission to go outside and smoke a cigarette. A journalist who interviewed him just prior to the judgment observed, 'His hands trembled.... The strain of ten days in court was clear in his gestures, inability to concentrate and sudden emotional outbursts.' He said if he were jailed his family would be 'destitute'. ${ }^{103}$

Justice James found both men guilty, Crichton on sixteen counts and Watts on twentyfour. The judge declared he found the duty to pass sentences on the men 'one of agonizing difficulty', for on the one hand the law had to be upheld but on the other hand 'the Court must take into account the tremendous pressures placed on medical men and those of lesser skill by desperate women who feel their whole social and economic future is bound up in getting rid of an unwanted pregnancy'. Bringing additional pressure to bear upon the government, James also observed that 'the situation regarding illegal abortions in this part of the country appears to have become most serious, and appears to require some sort of official action... and it is the function of the legislature to amend the law...' ${ }^{104}$ The Sunday Express headline of 10 December 1972 read: 'Judge favours law reform on illegal abortions'.

In his judgment James's opinion about the two men could not have been more different; a clear reflection of his class-biased interpretation of their actions. For the uneducated Watts he had no sympathy. Though doctors in Durban had expressed being 'amazed at the skill displayed by Watts in inducing abortions' and witnesses had testified to his diligence and kindness, the judge decided Watts was a mercenary opportunist. James did acknowledge Watts 'took pains about avoiding infection' and 'treated the women with consideration', but nevertheless sentenced him to two years in prison, with one year conditionally suspended. ${ }^{105}$ His attitude was not unique to South Africa. In the 1950s, for example, American judges and prosecutors found the economic motive for performing abortions 'particularly disgusting'; in sexist societies it is seen as 'immoral for anyone to benefit from the irresponsible sexual behaviour of a woman'. ${ }^{106}$ The lack of respect was mutual: Watts later referred to James as 'a pompous old fart' ${ }^{107}$ In sharp contrast the judge was greatly impressed by Crichton, describing him as a noble man with a history of tremendous service to the community. ${ }^{108} \mathrm{He}$ believed Crichton was compassionate, not greedy, and had acted only in the best interest of his patients. Nevertheless, he said, given the existing law, his hands were tied and knowing a criminal conviction would inevitably bring harm to Crichton's stellar career he fined him only R500.

The convictions had a hugely differential impact on the two men's careers. Ironically, for Watts, the untrained abortionist Justice James dismissed as simply greedy, imprisonment

\footnotetext{
102 Ibid.

103 op. cit. (note 45) Natal Mercury, 9 December 1972.

104 'Judge Favours Law Reform on Illegal Abortions', Sunday Times, 10 December 1972.

105 'Judgment', Crichton Watts Trial Transcript, 740.

106 Solinger, The Abortionist, 38-9.

107 James Watts, interviewed at home, 2 December 2009.

108 'Judgment', Crichton-Watts Trial Transcript.
} 
merely imposed a temporary halt to his abortion business. He served six months at Durban Central Prison and after his release immediately resumed performing abortions. In fact, Watts was an abortionist for another 20 years. ${ }^{109}$ Because of the near-impossibility of procuring a legal abortion during the apartheid era, South African women of all 'races' continued seeking the services of clandestine abortionists. As for Crichton, a few months after the conviction he once again stood trial, this time alongside Dr Angini Maharaj. Both were found guilty and subsequently struck off the medical roll, which barred them from practicing and teaching medicine in South Africa. This had a devastating effect on their careers. Crichton left South Africa for Swaziland in 1974, one of few jurisdictions that would allow him to practice medicine, and repeatedly applied for reinstatement to the medical roll. He returned to South Africa in 1977 after reinstatement and opened a private practice, but his academic career was finished.

\section{Conclusion}

The prosecution of Crichton and Watts revealed with supreme clarity the contested nature of the terrain of sex and reproduction in South Africa during apartheid. The trial heightened the visibility of young white women's 'errant' sexuality, which intensified patriarchal anxiety about the disintegration of the traditional family. Clearly, many 'ordinary girls' were choosing to have pre-marital sex and avoid motherhood, and with the help of doctors like Crichton were finding ways to do so. In subsequent discussion and debate about abortion leading up to the passage of the Act the theme of the wayward white daughter was a leitmotif. ${ }^{110}$

At an official level the trial played a role, albeit indirectly, in the production of South Africa's first statutory law on abortion - the extremely restrictive Abortion and Sterilisation Act (1975). Reflecting the regime's double determination to police white girls' sexuality and the medical profession, the Act contained so many byzantine limitations and bureaucratic requirements for both women and doctors that obtaining a legal abortion became all but impossible for the remainder of apartheid. ${ }^{111}$ Among the many new regulatory requirements put in place the law stipulated that a doctor could perform an abortion only in a state-controlled institution after receiving written permission from the official in charge, who then must submit the name of the doctor to the Minister of Health within twenty-one days after the procedure. Doctors who performed a suspiciously high number of abortions could then be investigated. During the debate in parliament preceding the passage of the Act, the Minister of Health, Dr S.W. van der Merwe, claimed with smugness this would help expose medical 'snakes in the grass'. ${ }^{112}$

To abortionists, medical and non-medical alike, it must have seemed as if almost overnight abortion transmogrified from a nominally criminal practice largely tolerated by police to a serious criminal act. Yet the effect of the Crichton-Watts affair on the clandestine abortion industry was nil. Two weeks after Crichton's arrest the Sunday Tribune found an abortionist in Durban after just three hours of searching, and in the two months after Crichton and Watts were convicted five women in the city died and at least another 250 were admitted to hospital because of botched abortions. ${ }^{113}$

\footnotetext{
109 James Watts, interviewed at home 2 December 2009.

110 See Klausen, op. cit. (note 8).

111 Ibid.

112 Republic of South Africa, House of Assembly Debates (Hansard), Third Session-Fourth Parliament, 14 February 1972, column 735 .

113 'Abortion Shock - 5 Deaths in Durban', Daily News, 17 February 1973.
} 
The chilling effect on the medical profession, however, was immediate and considerable. Doctors previously willing to perform abortions had learned the lesson that the government wanted to teach them by seriously damaging the career of so eminent a doctor as Crichton: the state was powerful and relentless, able to spend seemingly unlimited funds to expose and prosecute them. As a result they became extremely wary of performing even legal therapeutic abortions, never mind illegal ones. Complaints were soon lodged that a medical abortion for what previously would have been considered a legitimate reason was next to impossible to obtain. ${ }^{114}$ In May 1974 an anonymous gynaecologist told a newspaper 'the police clampdown' had ended sympathetic doctors' willingness to perform abortions, which had the dual effect of eliminating from the field 'those qualified medical practitioners who were prepared to perform abortions safely' and encouraging the proliferation of 'backstreet operators'. ${ }^{115}$ Some doctors did continue to perform abortions clandestinely but if caught were also harshly treated. In 1977, for example, Dr Philippus Lodewyk Jacobus Smith, aged 50, of Ottosdal was sentenced to a prison term for performing abortions, free of charge, on three white university students. Convicted in February 1976, he was already in prison when the Disciplinary Committee of the Medical and Dental Council held a hearing about his case, and he was brought manacled before the committee. He pleaded guilty to the charge of disgraceful conduct and said in mitigation 'he gave in to pleadings from the three girls to do the abortions. He felt very sorry for the girls, who were facing scandal and an end to their university careers.' He was struck off the medical register and returned to prison. ${ }^{116}$ Afterwards, a gynaecologist who for forty years had believed in abortion law reform, Dr E.W. Bischoff, told a meeting of members of the feminist group Abortion Reform Action Group, 'A doctor has no rights today.' 117 This had little impact on women of other 'races' who had little to no access to medical abortion in the first place. But in the aftermath of the downfall of Crichton and until the demise of apartheid, white girls and women in South Africa found it harder to have safe medical abortions. ${ }^{118}$ Which is precisely what the NP Government wanted.

\footnotetext{
114 E.g., 'No Abortion for LSD Girl Who Can't Look After Baby', Sunday Tribune, 4 March 1973.

115 'Focus on Abortion', Sunday Tribune, 16 May 1974.

116 'Doctor, in Gaol, Now Struck Off', Natal Mercury, 8 June 1977.

117 Cited in Cope, op. cit. (note 29), 113.

118 South Africa became a liberal democracy in 1994, and in 1996 the newly-elected ANC government passed the Choice on Termination of Pregnancy Act that allows for abortion on demand without restriction as to reason, but with gestational limits.
} 